\title{
Seasonal variations in the rates of calcification and productivity in the coral Acropora formosa on a high-latitude reef
}

\author{
C. J. Crossland \\ Division of Fisheries Research, CSIRO Marine Laboratories, P. O. Box 20, North Beach, Western Australia 6020
}

\begin{abstract}
Branches of Acropora formosa colonies from a high-latitude reef (Houtman Abrolhos Islands, Western Australia, $29^{\circ} \mathrm{S}$ latitude) were incubated with ${ }^{45} \mathrm{Ca}$ and ${ }^{14} \mathrm{C}$ in photosyntheticallysaturating light at ambient water temperatures. Seasonal changes in calcification rate $\left({ }^{45} \mathrm{Ca}\right.$ and ${ }^{14} \mathrm{C}$ incorporation) and net ${ }^{14} \mathrm{C}$-productivity were determined. While calcification was depressed by winter temperatures $\left(17.7^{\circ} \mathrm{C}\right.$ minimum), it did not cease. Net ${ }^{14} \mathrm{C}$-productivity was evaluated after fractionation of coral tissues. Carbon incorporation into the storage-structural tissue fraction was reduced by winter temperatures and apparently ceased at $17.7^{\circ} \mathrm{C}$. The winter temperature minimum is considered to be a primary determinant and light a secondary determinant for growth and survival of Acropora formosa in this high-latitude reef.
\end{abstract}

\section{INTRODUCTION}

Strong seasonality has been shown in calcification and gross organic carbon productivity in an Acroporadominated reef community in the high latitude (28 to $\left.29^{\circ} \mathrm{S}\right)$ Houtman Abrolhos Islands (Smith, 1981). Further, the growth rates of Acropora formosa and Pocillopora damicornis are severely curtailed in winter, to one-fifth that of summer values (Crossland, 1981). While competition with seasonally abundant macroalgae is a factor determining coral growth and survival (Johannes et al., 1983), low water temperatures and reduced daily solar irradiance in winter also affect coral metabolism and calcification (Crossland, 1981).

Little information is available regarding the direct effects of temperature on coral metabolism and growth. Some quantitative data have been obtained from field studies involving ambient seawater temperature changes (Ma, 1937; Shinn, 1966; Glynn and Stewart. 1973) and from laboratory or field temperature manipulation studies (Clausen, 1971; Jokiel and Coles. 1974; Clausen and Roth, 1975a, b; Coles, 1975; Coles et al., 1976; Coles and Jokiel, 1977, 1978). The latter investigations have evaluated the effects of elevated temperature regimes on coral physiology and frequently involved imposition of short-term (hours to days) temperature manipulations.
This study reports the effect of seasonal changes in ambient seawater temperature on calcification $\left({ }^{45} \mathrm{Ca}\right.$ and ${ }^{14} \mathrm{C}$-incorporation) and net ${ }^{14} \mathrm{C}$-productivity by Acropora formosa at a high latitude extreme. Shortterm (90 $\mathrm{min}$ ) radioisotope incubations of coral branches from shallow water colonies were carried out throughout the year at ambient water temperatures (down to $17.7^{\circ} \mathrm{C}$ ) under photosynthetically-saturating light intensities. These conditions ensured the coral branches were naturally adapted to ambient temperature and not subjected to manipulative thermal stresses prior to or during experimentation.

\section{METHODS AND MATERIALS}

Collection of specimens. Colonies of the Staghorn Coral Acropora formosa were collected at intervals of 4 to 6 wk (June 1979-July 1980) from 2 to $3 \mathrm{~m}$ water depth on a patch reef north of Rat Island, Houtman Abrolhos Islands, Western Australia. The corals were resubmerged in subdued light (200 to $300 \mu \mathrm{Ein} \mathrm{m}^{-2} \mathrm{~s}^{-1}$ ) and transported to the field station jetty on Rat Island.

Terminal $3 \mathrm{~cm}$ lengths of branch were cut and placed in circular perspex racks (6 branches per rack) in flowing seawater for $1.5 \mathrm{~h}$ prior to each incubation period. Branches for dark incubations were kept in complete darkness during this and the radioisotopic 
incubation periods while those for light-incubations were kept under natural photosynthetically-saturating daylight conditions (Crossland and Barnes, 1977a). Ambient temperature seawater was continuously pumped from below the jetty to bathe the incubation beakers.

Incubation solution. Coral branches were incubated in $300 \mathrm{ml} 0.45 \mu \mathrm{m}$ membrane-filtered seawater containing either $1.0 \mathrm{ml}$ of $\mathrm{NaH}^{14} \mathrm{CO}_{3}$ solution $\left(100 \mathrm{MBq}{ }^{*}\right.$; specific activity $1.87 \mathrm{MBq}, \mu \mathrm{mole}^{-1}$ dissolved inorganic carbon) or $0.4 \mathrm{ml}$ of $\mathrm{CaCl}_{2}$ solution $(12.5 \mathrm{MBq}$, specific activity $0.37 \mathrm{GBq}, \mathrm{mg}^{-1} \mathrm{Ca}$ ).

Incubations. Fifteen min prior to each incubation, $150 \mathrm{ml}$ of incubation solution was added to each of $250 \mathrm{ml}$ glass beakers. Beakers for dark incubations were enclosed in aluminium foil. For specific activity determinations, a $50 \mu \mathrm{l}$ sample was transferred from each beaker to either $1 \mathrm{ml} \mathrm{N} \mathrm{KOH}\left({ }^{14} \mathrm{C}\right)$ or $1 \mathrm{ml} \mathrm{N} \mathrm{HCl}$ $\left({ }^{45} \mathrm{Ca}\right)$. At $\mathrm{t}_{0}$, a rack of coral branches was transferred to each incubation beaker; ${ }^{14} \mathrm{C}$-light, ${ }^{14} \mathrm{C}$-dark, ${ }^{45}$-Calight and ${ }^{45} \mathrm{Ca}$-dark.

For ${ }^{14} \mathrm{C}$-incubations, throughout a time course $(5,10$, $20,40,60,90 \mathrm{~min}$ ), a coral branch was removed from each beaker and washed briefly in flowing seawater. The basal $0.5 \mathrm{~cm}$ of the branch was cut and discarded (Muscatine and Cernichiari, 1969) before extraction at $4{ }^{\circ} \mathrm{C}$ in $15 \mathrm{ml}$ methanol : chloroform : water (12:5:3) (MCW) (Bieleski and Turner, 1966).

For ${ }^{45} \mathrm{Ca}$-incubations, after $90 \mathrm{~min}$ the 2 sets of 6 replicate coral branches were transferred to fast-flowing seawater $\left(61 \mathrm{~min}^{-1}\right.$ ) for $90 \mathrm{~min}$ in the dark prior to similar extraction in $\mathrm{MCW}$. The wash-out treatment minimised residual ${ }^{45} \mathrm{Ca}$ in the coral tissues which otherwise would have contributed to radioisotopic counting errors.

Sample analyses. All branch samples were stored for $48 \mathrm{~h}$ prior to analysis at the North Beach Laboratories. A constant time for MCW extraction of organic compounds and removal of tissues from skeletons with $\mathrm{KOH}$ is critical to reduce intersample variations due to radioisotopic exchange-precipitation phenomena (Barnes and Crossland, 1977; Crossland and Barnes, 1977b).

For ${ }^{14} \mathrm{C}$ analyses, tissues and skeleton from each coral branch were fractionated and ${ }^{14} \mathrm{C}$-incorporation determined as previously described (Crossland et al., 1980a). The MCW solution from each branch was separated into two fractions; a chloroform fraction (lipids and photosynthetic pigments) and a methanol-water (MeOH-W) fraction (amino acids-ureides, organic acids, neutral compounds). Radioactivity was determined in aliquots of each fraction after acidification

\footnotetext{
- Radioactivity is expressed in $\mathrm{S} I$ units, where $1 \mathrm{~Bq}=1$ disintegration $\mathrm{s}^{-1}(\mathrm{dps}) ; 1 \mu \mathrm{Ci}=3.7 \times 10^{4} \mathrm{~Bq}$
}

with $\mathrm{N} \mathrm{HCl}$ to remove ${ }^{14} \mathrm{CO}_{2}$ i the chloroform fraction was evaporated to dryness prior to acidification. The MCW-insoluble tissue fraction digested from each coral branch with $\mathrm{N}$ KOH was acidified with $2 \mathrm{~N} \mathrm{HCl}$ and radioactivity determined. The tissue-free coral skeleton was dissolved in $\mathrm{N} \mathrm{HCl}$ the ${ }^{14} \mathrm{CO}_{2}$ collected and ${ }^{14} \mathrm{C}$-incorporation determined.

For ${ }^{45} \mathrm{Ca}$ samples, each coral branch was transferred to a clean glass vial and the MCW solution discarded. Tissues were digested from the skeleton with $\mathrm{N} \mathrm{KOH}$ before dissolving the $\mathrm{CaCO}_{3}$ in $\mathrm{N} \mathrm{HCl}$. The ${ }^{45} \mathrm{Ca}$ associated with the skeleton was determined.

Determination of radioactivity. Instagel was added to aqueous samples and radioactivity was determined with a Packard Tricarb Liquid Scintillation Spectrometer. The cpm were corrected to Bq using the external standard ratio method and appropriate quench standards.

Protein determinations. A $200 \mu \mathrm{l}$ sample of the $\mathrm{KOH}$ digest from each coral branch were assayed for protein (Lowry et al., 1951) with bovine serum albumen standards.

Analyses of data. ${ }^{14} \mathrm{C}$ time-course data were graphed and fitted to standard equations viz., linear ( $y=$ $a+k t)$, exponential $\left(y=a e^{k t}\right)$, power $\left(y=a t^{k}\right)$ and limit $\left(y=a\left[l-e^{-k t}\right]\right)$, where $y={ }^{14} \mathrm{C}$ incorporated into the tissue fraction or skeleton $\left(\mathrm{Bq}, \mathrm{mg}\right.$ protein $\left.{ }^{-1}\right)$; $t=$ elapsed time of incubation (min). Curve fitting was made with the Simulation, Analysis and Modelling SAAM-25 program (Berman \& Weiss, 1967) through CSIRONET facilities.

The ${ }^{45} \mathrm{Ca}$ incorporated by the skeleton was expressed as mean value of radioactivity (Bq, Img protein $^{-1} \mathrm{~h}^{-1}$ ) \pm standard deviation of the six coral branch replicates used in each incubation of the seasonal experiments.

\section{RESULTS}

The water temperatures at the experimental site ranged from $17.7^{\circ} \mathrm{C}$ (August minimum) to $24.8^{\circ} \mathrm{C}$ (January maximum) (Fig. 1a) and are comparable with the mean monthly surface water temperatures for Rat Island (CSIRO Marine Laboratories, W. A.; unpubl. 1971-81). The daily incident solar radiation for Rat Island has not been recorded but probably is similar to that of mainland Geraldton (Fig. 1b), with a December maximum for daily radiation becoming reduced by ca. $65 \%$ at the June minimum.

The kinetics of ${ }^{14} \mathrm{C}$-incorporation into the $\mathrm{MCW}$ fraction and the MCW-insoluble fraction of coral tissues were described by a limit-curve function, and the chloroform fraction by a power curve function. These kinetic functions characterizing each gross metabolic pool are similar to those determined previously for low 


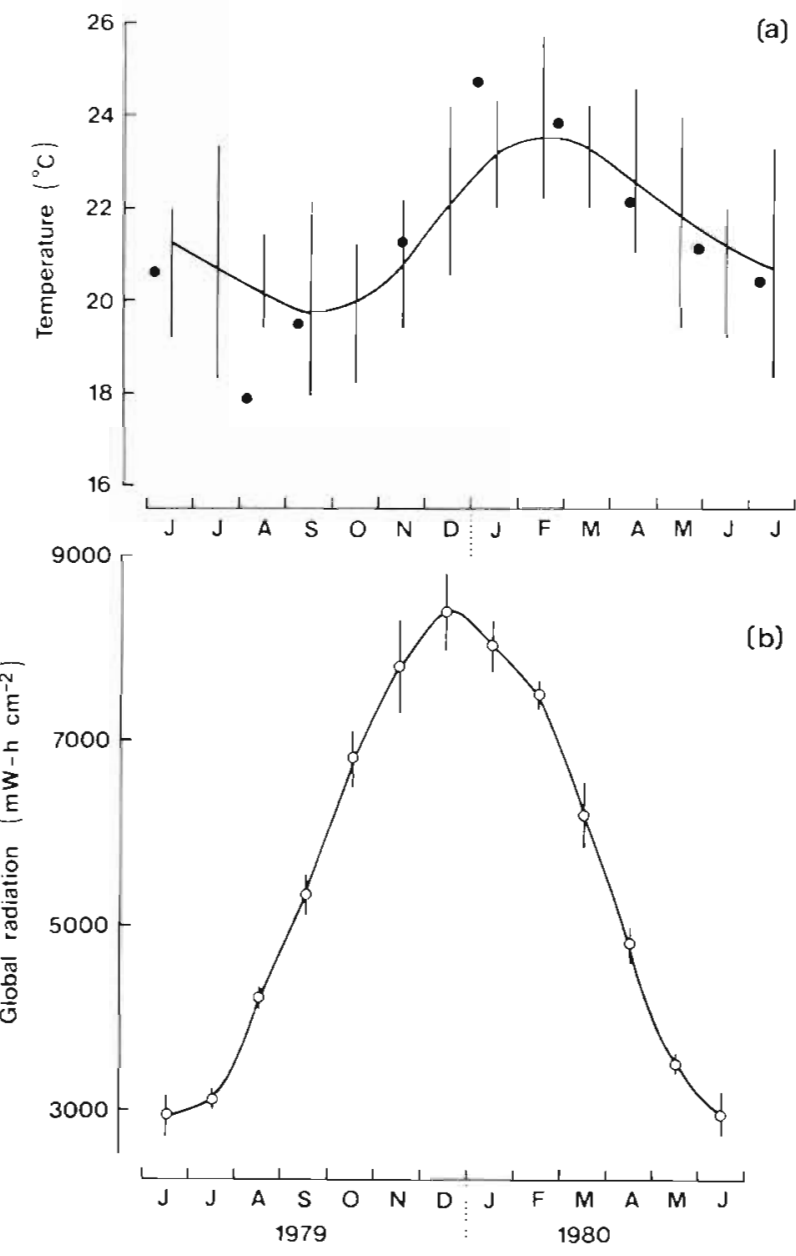

Fig. 1. (a) Mean monthly ambient water temperatures \pm standard deviation (near Rat Island, Houtman Abrolhos Islands, 1971-81). Closed circles: ambient temperature of radioisotopic incubation experiments. (b) Mean monthly incident solar irradiance \pm standard deviation (Geraldton, 1969-81)

latitude colonies of Acropora formosa (Crossland and Barnes, submitted).

Seasonally there was no statistically significant variation in either the relative metabolic pool size (a) or the fractional turnover rate $(k)$ of the $\mathrm{MeOH}-\mathrm{W}$ fraction from tissues of coral branches ${ }^{14} \mathrm{C}$-incubated in either light or dark conditions (Fig. 2). Similarly, the chloroform fraction showed no variation in ${ }^{14} \mathrm{C}$-incorporation (Fig. 3). The ${ }^{14} \mathrm{C}$-incorporation by the chloroform fraction in these short-term incubations ( 5 to $90 \mathrm{~min}$ ) was strongly light dependent; dark incorporation was $<0.01 \%$ of that in the light. Thus, under photosynthetically-saturating light conditions, carbon incorporation into both the pool of small molecular weight metabolic intermediates (MeOH-W) and the pool of lipids (chloroform) of coral tissues was independent of seasonal changes in seawater temperature.

${ }^{14} \mathrm{C}$-incorporation into the $\mathrm{MCW}$-insoluble fraction
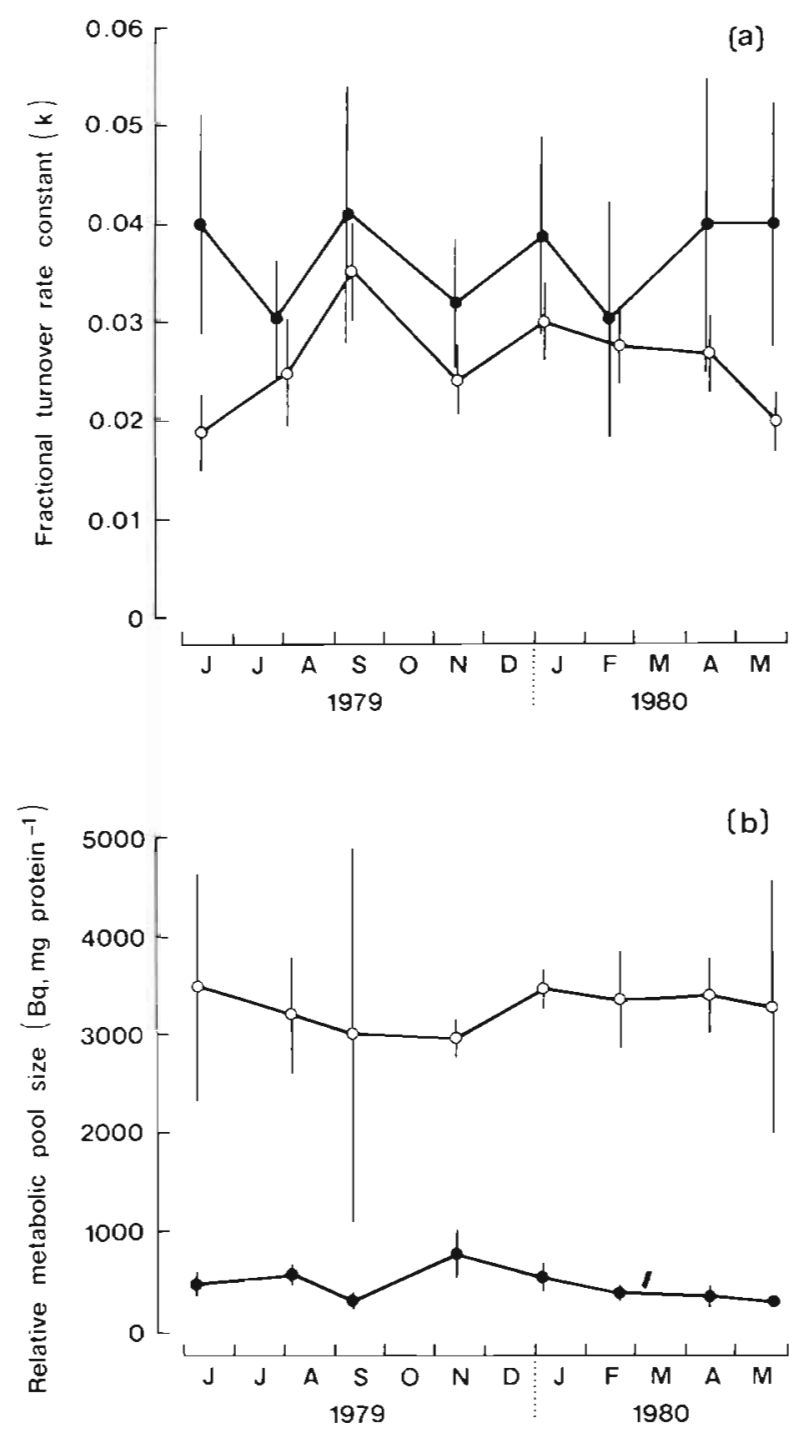

Fig. 2. Seasonal variation in (a) fractional turnover rate of ${ }^{14} \mathrm{C}$ and (b) metabolic pool size of the $\mathrm{MeOH}-\mathrm{W}$ fraction of tissues from light-incubated (open circles) and dark-incubated (closed circles) coral branches. Error bars: fractional standard deviation

of coral branch tissues (Fig. 4) showed marked patterns of change. Variations in relative metabolic pool size followed those of seawater temperature, with minimum pool size occurring during the lowest winter temperatures $\left(17.7^{\circ} \mathrm{C}\right.$, August). Perhaps of greater significance is the seasonal pattern in the fractional turnover rate for the MCW-insoluble fraction. Here, during the period of lowest water temperatures the fractional turnover rate of carbon incorporation virtually ceased ( $\mathrm{k}<0.001$ in light; $\mathrm{k}<0.0001$ in dark). Coincident with the subsequent increase in water temperature to $19.5^{\circ} \mathrm{C}$ for the September incubation was a major peak in fractional turnover rate for carbon into this metabolic pool. 


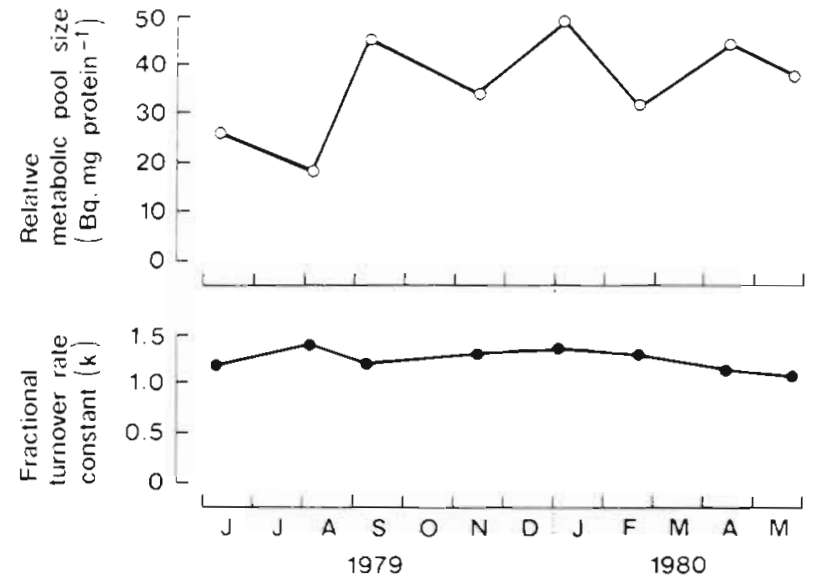

Fig. 3. Seasonal variation in metabolic pool size (open circles) and fractional turnover rate (closed circles) of ${ }^{14} \mathrm{C}$ by the chloroform fraction of tissues from light-incubated coral branches

Short-term (90 min) ${ }^{14} \mathrm{C}$-incorporation into coral skeleton showed linear kinetics in dark incubation conditions, but non-linear kinetics in the light. The latter were described by an exponential function. Both light-treated and dark-treated coral showed a seasonal change in ${ }^{14} \mathrm{C}$ incorporation into the skeleton with highest rates occurring during the higher water temperatures of summer (Fig. 5). Companion studies with ${ }^{45} \mathrm{Ca}$ showed a similar seasonal pattern (Fig. 6), with light: dark incorporation ratios ranging from 3.0 (August 1979) to 9.5 (January 1980). While the lowest calcification rates coincided with lowest water temperatures, radioisotopic incorporation of both ${ }^{14} \mathrm{C}$ and ${ }^{45} \mathrm{Ca}$ was sustained at readily detectable rates. Light and dark ${ }^{14} \mathrm{C}$-calcification rates are not directly comparable. However, ${ }^{45} \mathrm{Ca}$-calcification rates were always greater in the light (Fig. 6). Thus, at a water temperature of $17.7^{\circ} \mathrm{C}$, radioisotopic incorporation into the skeleton was a result of tissue-mediated calcification processes not solely physical radioisotopic exchange (Chalker and Taylor, 1975; Chalker, 1976).

\section{DISCUSSION}

Calcification rates of Acropora formosa are reduced seasonally by the water temperature regime of the Houtman Abrolhos Islands. This is reflected in seasonal growth rates (Crossland, 1981). However, in photosynthetically-saturating light skeletal deposition of calcium carbonate proceeds at $17.7^{\circ} \mathrm{C}$, albeit at a low rate.

In photosynthetically-saturating light and ambient water temperature, net ${ }^{14} \mathrm{C}$-productivity $\left({ }^{14} \mathrm{C}\right.$-fixed and retained by coral tissues) of Acropora formosa from the
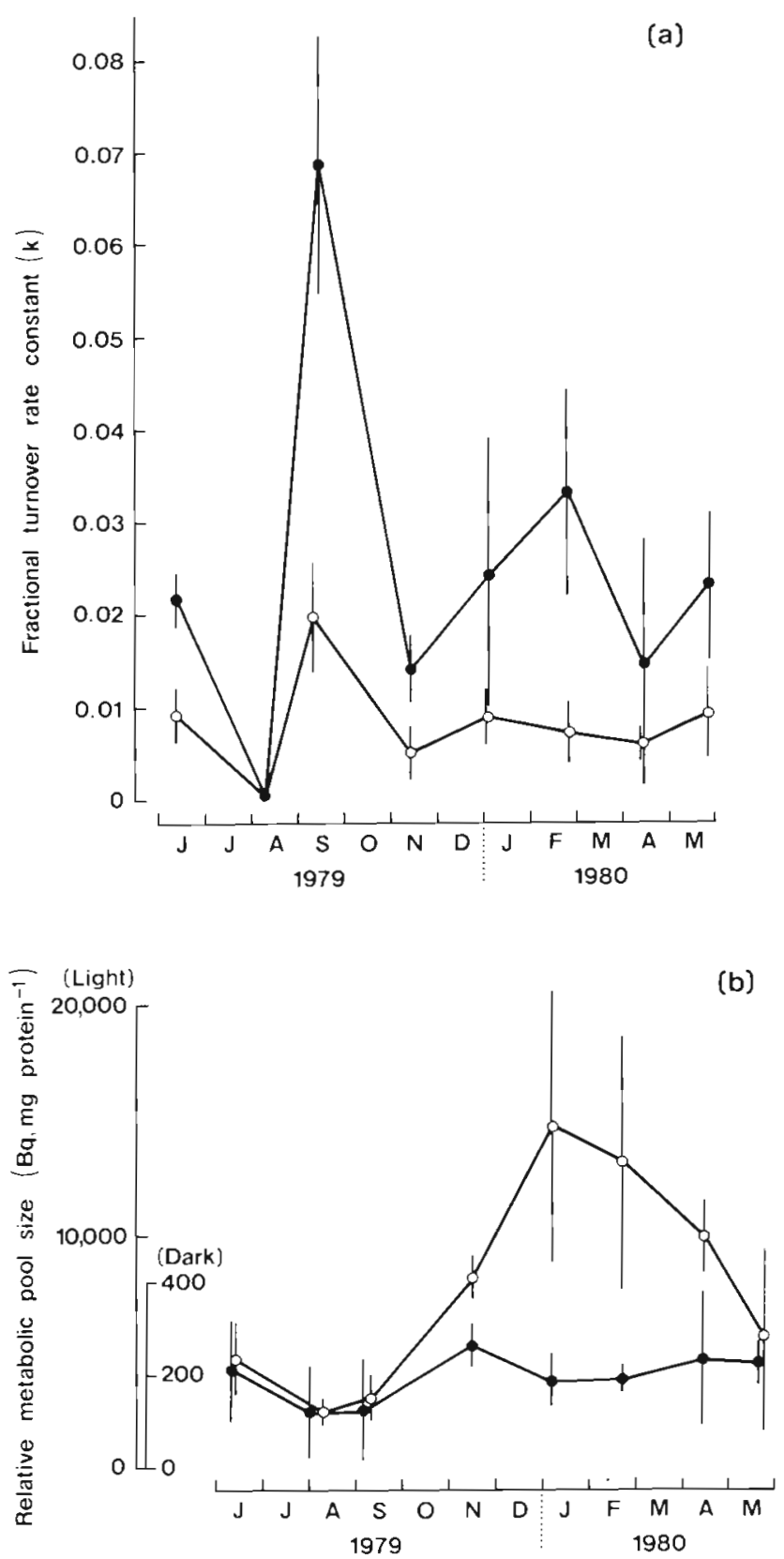

Fig. 4. Seasonal variation in (a) fractional turnover rate of ${ }^{14} \mathrm{C}$ and (b) metabolic pool size of the MCW-insoluble fraction of tissues from light-incubated (open circles) and dark-incubated (closed circles) coral branches. Error bars: fractional standard deviation

Houtman Abrolhos Islands showed no significant seasonal changes when whole tissues were analysed after 60 or 90 min incubation (Crossland, 1981). The nonlinear kinetics of ${ }^{14} \mathrm{C}$-incorporation into the lipid fraction of the coral tissues obscures changes in carbon metabolism by other metabolic pools (Crossland, 1980; Crossland et al., 1980b); ca. 60 to $70 \%$ of ${ }^{14} \mathrm{C}$ is associated with lipids after $60 \mathrm{~min}$ incubation. However, 


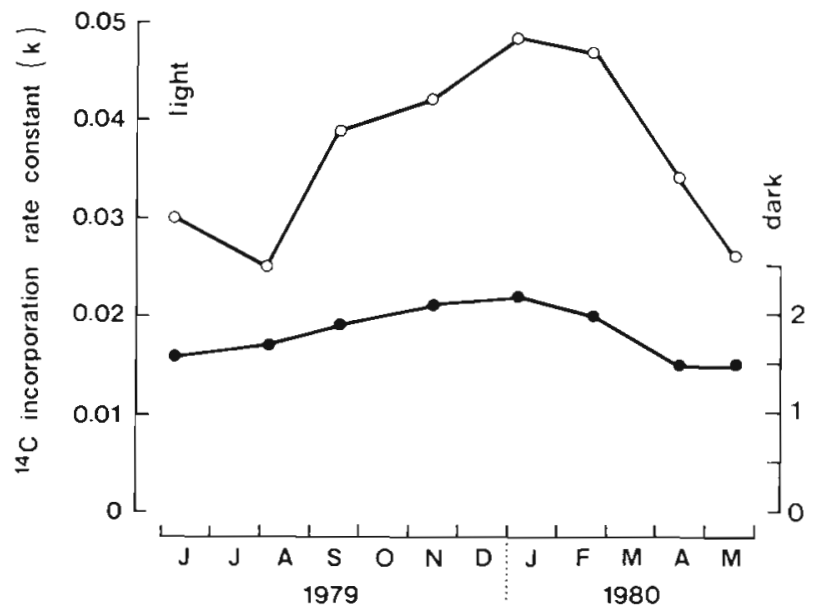

Fig. 5. Seasonal variation in rates of ${ }^{14} \mathrm{C}$-incorporation into the skeleton of light-incubated (open circles, from power curve function) and dark-incubated (closed circles, from linear curve function) of coral branches

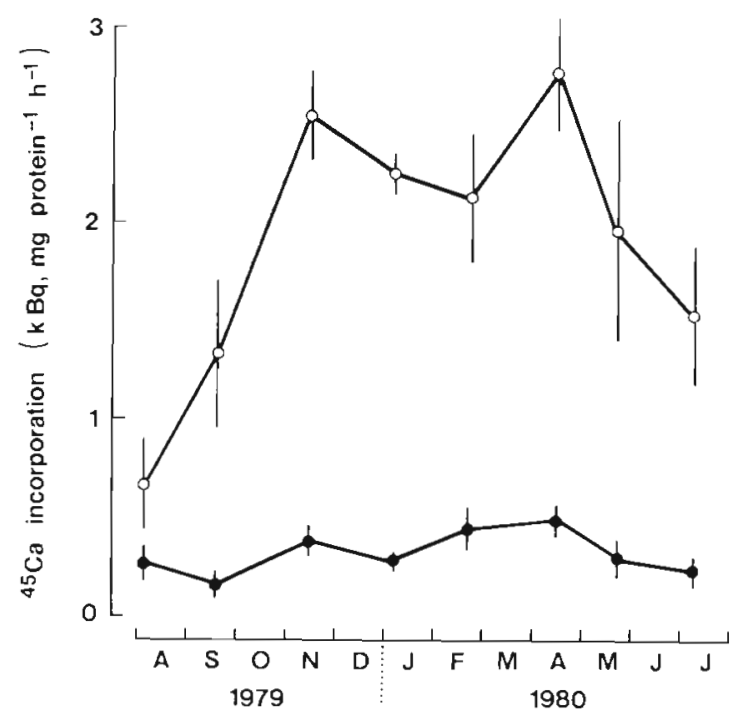

Fig. 6. Seasonal variation in rates of ${ }^{45} \mathrm{Ca}$-incorporation into the skeleton of light-incubated (open circles) and dark-incubated (closed circles) coral branches. Error bars: standard deviation

after fractionation of the gross metabolic compartments of the tissues into small molecular weight, intermediary metabolites (MeOH-W), lipids (chloroform), storage polymers and structural tissues (MCW-insoluble) marked seasonal changes were apparent only for ${ }^{14} \mathrm{C}$ incorporation into the $\mathrm{MCW}$-insoluble fraction. Here, both the fractional turnover rate of carbon incorporation and metabolic pool size was lowest during the winter.

Reduction in metabolic pool size of the storagestructural tissue fraction in winter parallels the decreasing seawater temperature. Pool size, however, reflects the immediate metabolic history of the coral tissues. It is probable that in winter the decreasing daily solar irradiance, i.e. $65 \%$ reduction from summer to winter (Fig. 1), interacts with temperature to yield a smaller carbon pool in the storage-structural tissue fraction; the intermediary carbon compounds being immediately utilized in maintaining basic metabolic functions such as respiration and ancillary energydemanding processes e.g. calcification (Chalker, 1976), lipid synthesis and transfer (Crossland et al., 1980b).

FIactional turnover rate (FTR) of the storage-structural tissue fraction under photosynthetically-saturating light conditions (Fig. 4a) seemed little affected by reduced water temperature, except in August 1979. However, FTR is defined as moles ${ }^{14} \mathrm{C}$-incorporated $\min ^{-1}$ mole $^{-1} \mathrm{C}$ in the metabolic pool and is thus a function of the metabolic pool size. Hence, as pool size decreased the amount of carbon transferred to the storage-structural tissue pool also decreased. Thus, with reduced light and water temperatures, the longterm organic storage pools become depleted and the potential for tissue repair and growth processes is diminished.

In August 1979, there was an extreme excursion in water temperature to $17.7^{\circ} \mathrm{C}$; this temperature was sustained for at least $6 \mathrm{~d}$. Thermal variations of this magnitude apparently are not infrequent in waters of the Houtman Abrolhos Islands (Wilson and Marsh, 1979). During this period, the FTR for carbon incorporation into the storage-structural tissue fraction was not significantly different from zero. This indicates that with sustained low water temperatures tissue maintenance and growth will cease and may ultimately lead to mortality of the Acropora formosa colonies unless heterotrophic nutrition can supply the necessary metabolic requirements. Thus, between 19.5 and $17.7^{\circ} \mathrm{C}$ water temperature rather than light becomes the determinant physical factor for $A$. formosa following an autotrophic mode of nutrition. No information is available regarding either the ability and efficiency of A. formosa to feed heterotrophically or the metabolic pathways and fate of carbon derived from this nutritional mode.

At the high latitudes of the Houtman Abrolhos Islands, the depressed winter growth rates for Acropora formosa (Crossland, 1981) reflect reduced calcification and reduced net carbon productivity resulting from low water temperatures and daily solar irradiance. In coral colonies preconditioned by these winter environmental factors, sustained low temperatures ( $<$ ca. $18^{\circ} \mathrm{C}$ ) halt tissue growth; under these conditions colony growth is limited by tissue growth and not skeletal formation. Hence, the high latitude survival of $A$. formosa appears to be determined primarily by temperature. Light would act as a secon- 
dary factor in deeper water colonies by further modifying net productivity and the coral's capacity for growth. If this environmental control is common to other Acroporid corals, the main reef-forming corals of the Indo-Pacific region, then this study provides an insight into a physiological mechanism involved in determining their latitudinal distribution. At the same time, it supports Wells' statement that 'no significant reefs occur when temperatures during the year fall below $18^{\circ} \mathrm{C}$, except for short periods', although his conclusions were based on the influence of temperature on sexual reproduction in corals. However, physiographic factors are not the sole determinant of coral growth and survivorship in high-latitude reef environments, but may interact with biotic phenomena (Crossland 1981; Johannes et al, 1983).

Acknowledgements. I wish to thank colleagues from the CSIRO Coastal Ecology Programme, North Beach for their assistance and advice; especially Dr. D. F. Smith and Ms. S. M. J. Horner for SAAM analyses and Mr. L. Olsen for field assistance

\section{LITERATURE CITED}

Barnes, D. J., Crossland, C. J. (1977), Coral calcification: sources of error in radioisotope techniques. Mar. Biol. 42 $119-129$

Berman, M., Weiss, M. F. (1967). SAAM Manual. NIHS PHS Publication, 1703

Bieleski, R. L., Turner, N. A. (1966). Separation and estimation of amino acids in crude plant extracts by thin-layer electrophoresis and chromatography. Analyt. Biochem. 17: 278-293

Chalker, B. E. (1976). Calcium transport during skeletogenesis in hermatypic corals. Comp. Biochem. Physiol 54A: $455-459$

Chalker, B. E., Taylor, D. L. (1975). Light-enhanced calcification, and the role of oxidative phosphorylation in calcification of the coral Acropora cervicornis. Proc. R. Soc. Lond. (Ser. B) 190: 323-331

Clausen, C. D. (1971). Effects of temperature on the rate of ${ }^{45}$ calcium uptake by Pocillopora damicornis. In: Lenhoff, H. M., Muscatine, L., Davis, L. V (ed.) Experimental coelenterate biology. University of Hawaii Press, Honolulu, p. $246-259$

Clausen, C. D., Roth, A. A. (1975a). Estimation of coral growth rates from laboratory ${ }^{45} \mathrm{Ca}$-incorporation rates. Mar. Biol 33: 85-91

Clausen, C. D., Roth, A. A.(1975b). Effect of temperature and temperature adaptation on calcification rate in the hermatypic coral Pocillopora damicornis. Mar. Biol. 33 93-100

Coles, S. L. (1975). A comparison of effects of elevated temperature versus temperature fluctuations on reef corals at Kahe Point, Oahu. Pacif. Sci. 29: 15-18

Coles, S. L., Jokiel, P. L. (1977); Effects of temperature on photosynthesis and respiration in hermatypic corals. Mar. Biol. 43: 209-216
Coles, S. L., Jokiel, P. L. (1978). Synergistic effects of temperature, salinity, and light on the hermatypic coral Montipora verrucosa. Mar. Biol. 49: 187-195

Coles, S. L., Jokiel, P. L., Lewis, C. R. (1976). Thermal tolerance in tropical versus subtropical Pacific reef corals. Pacif. Sci. 30: 159-166

Crossland, C. J. (1980). Release of photosynthetically-derived organic carbon from a hermatypic coral, Acropora cf. acuminata. In: Schwemmler, W., Schenk, H. E. A. (ed.) Endocytobiology, endosymbiosis and cell biology. Walter de Gruyter and Co., Berlin, New York, p. 163-172

Crossland, C. J. (1981). Seasonal growth of Acropora cf. formosa and Pocillopora damicornis on a high latitude reef (Houtman Abrolhos, Western Australia). Proc. IVth Int. Coral Reef Symp., Manila, Vol. I, p. 663-667

Crossland, C. J., Barnes, D. J. (1977a). Gas-exchange studies with the Staghorn Coral Acropora acuminata and its zooxanthellae. Mar. Biol. 40: 185-194

Crossland, C. J., Barnes, D. J. (1977b). Calcification in the staghorn coral Acropora acuminata: variations in apparent skeletal incorporation of radioisotopes due to different methods of processing. Mar. Biol. 43: 57-62

Crossland, C. J., Barnes, D. J. Fixation and distribution of ${ }^{14} \mathrm{C}$ in the Staghorn Coral Acropora acuminata. I. Diurnal variation. J. exp. mar, Biol. Ecol. (submitted)

Crossland, C. J., Barnes, D. J., Cox, T., Devereux, M. (1980a). Compartmentation and turnover of organic carbon in the Staghorn Coral Acropora formosa. Mar. Biol. 59: 181-187

Crossland, C. J., Barnes, D. J., Borowitzka, M. A. (1980b). Diurnal lipid and mucus production in the Staghorn Coral Acropora acuminata. Mar. Biol. 60: 81-90

Glynn, P. W., Stewart, R. H. (1973). Distribution of coral reefs in the Pearl Islands (Gulf of Panama) in relation to thermal conditions. Limnol. Oceanogr. 18: 367-379

Johannes, R. E., Wiebe, W. J., Crossland, C. J., Rimmer, D. W. (1983). Latitudinal limits of coral reef growth. Mar. Ecol. Prog. Ser. 11: 105-111

Jokiel, P. L., Coles, S. L. (1974). Effects of heated effluent on hermatypic corals at Kahe Point, Oahu. Pacif. Sci. 28: 1-18

Lowry, O. H., Rosebrough, N. J., Farr, A. L., Randall, R. J. (1951). Protein measurement with the Folin phenol reagent. J. biol. Chem. 193: 265-275

Ma, T. Y. H. (1937). On the growth rate of reef coral and its relation to sea water temperature. Palaeont. sin. (Ser b) 16: $1-426$

Muscatine, L., Cernichiari, E. (1969). Assimilation of photosynthetic products of zooxanthellae by a reef coral. Biol. Bull. mar. biol. Lab., Woods Hole 137: 506-523

Shinn, E. A. (1966). Coral growth rate, an environmental indicator. J. Paleont. 40: 233-240

Smith, S. V (1981). The Houtman Abrolhos Islands: carbon metabolism of coral reefs at high latitudes. Limnol. Oceanogr 26: 612-621

Wells, J. W. (1957). Coral reefs. In: Hedgpeth, J. W. (ed.) Treatise on marine ecology and paleaecology, Vol. I, Ecology. Geological Society of America, New York, p. 609-631. (Mem. geol. Soc. Am. No. 67)

Wilson, B. R., Marsh, L. M. (1979). Coral reef communities at the Houtman Abrolhos, Western Australia, in a zone of biogeographic overlap. Proceedings of the International Symposium on Marine Blogeography and Evolution in the Southern Hemisphere, 1978. N. Z. DSIR Information Series 137: $259-278$ 